\section{Globalisering av klinisk forskning - etiske spørsmål}

Mer og mer klinisk forskning foregår i global skala. Mye amerikansk forskning utføres i andre land, ofte utviklingsland. En grunn til dette er de sterkt reduserte kostnadene ved å utføre fase 2- og 3-studier i f.eks. India eller Sør-Amerika - det kan koste mindre enn en tiendedel sammenliknet med USA. En artikkel i New England Journal of Medicine reiser spørsmål ved de etiske og vitenskapelige konsekvensene av denne trenden, når resultatene brukes til å godkjenne medikamenter for bruk i USA (1).

To viktige etiske spørsmål er om frivillige som inngår i slike studier er representative for fremtidige, amerikanske brukere, og om mange deltar fordi det sikrer dem tilgang til helsetjenester de ellers ikke hadde hatt mulighet for å få. Store forskjeller i utdanning, økonomi og helsetjenester kan true rettighetene til forskningsdeltakere. Det kan være manglende forståelse av medikamentene og av bruken av placebogrupper. Noen steder kan den økonomiske kompensasjonen være større enn deltakeres årlige inntekt, og deltakelse i kliniske studier kan være den eneste muligheten for behandling.

Det er også usikkert om deltakere i slike studier er representative for fremtidige, amerikanske brukere. Genetiske og miljømessige forskjeller kan gjøre at forskjellige befolkninger metaboliserer medikamenter ulikt (2).

- Dette skaper problemer med tolking av resultatene, sier førsteforfatter Seth W. Glickman.

Ezekiel Emanuel, leder for bioetikk ved Clinical Center of the National Institutes of Health, kritiserer artikkelen for å være for negativ. Han viser til en studie av HPV-vaksinen Gardasil i Costa Rica, hvor det er en høy insidens av livmorhalskreft.

- Dette er et eksempel på at globalisering også kan være bra, konluderer Emanuel.

\section{Oda Riska}

oriska@hotmail.com

Tidsskriftet

\section{Litteratur}

1. Glickman SW, McHutchison JG, Peterson ED et al. Ethical and scientific implications of the globalization of clinical research. N Engl J Med 2009; 360: 816-23.

2. Singer N. Outsourcing of drug trials is faulted. The New York Times 18.2. 2009. www. nytimes. com/2009/02/19/business/19clinic.html? $r=$ 2\&adxnnl=1 \& ref=health\&adxnnl $x=1237550463$ -Xqj20tsTKHiDRJp9ipZoiQ (20.3.2009)

\section{Forskning på diaré hos barn i u-land er nedprioritert}

\author{
Diaré hos barn krever nesten to millioner liv per år og er årsaken \\ til totalt $18 \%$ av dødsfall blant barn. Likevel er ikke dette et prioritert \\ forskningsområde. Forskning på type 2-diabetes blir tilgodesett \\ med ti ganger så mye midler som forskning på diaré sett i forhold \\ til sykdomsbyrden i befolkningen.
}

Det fjerde tusenårsmålet til FN er å redusere dødeligheten blant barn under fem år med to tredeler i perioden 1990-2015. Ferske beregninger viser ingen økning i reduksjonshastigheten, og det er fare for at man ikke når dette målet. Globalt er pneumoni den vanligste og diaré den nest vanligste dødsårsaken blant barn. Sammen utgjør dødsfall forårsaket av pneumoni og diaré hos barn en større andel enn dødsfall som tilskrives røyking, og dobbelt så mange dødsfall som hiv/ aids forårsaker årlig. I en artikkel nylig publisert i PLoS Medicine defineres prioriteringer innen diaréforskning basert på en metode utviklet av Child Health and Nutrition Research Initiative (1).

Områder det trengs videre forskning på for å bedre overlevelsen av diaré blant barn, er knyttet til helsesystemer, helsepolitikk og epidemiologiske spørsmål. Målet er at man gjennom denne type forskning kan finne løsninger knyttet til gjennomføring av tiltak, effektivitet og optimalisering av kjente tiltak, slik som orale rehydreringssalter løst i rent vann, sinktilskudd og morsmelkernæring. Dessverre er viktigheten av disse forskningsområdene lite anerkjent blant dem som finansierer forskningen, sannsynligvis fordi resultatene neppe vil medføre førstesideoppslag eller utvikling av kommersielle produkter.

Årlig brukes hele 126 milliarder amerikanske dollar til medisinsk forskning (tall fra 2003). Ser man på pengebruken i forhold til sykdomsjusterte leveår (disability adjusted life years, DALY), er det store ulikheter mellom ulike sykdomsgrupper. Det brukes mindre enn ti dollar per sykdomsjusterte leveår på diaréforskning, mot 102 dollar per sykdomsjusterte leveår til forskning på type 2-diabetes. Det er alvorlig at det fortsatt er så høy dødelighet pga. diaré når det finnes kostnadseffektive tiltak og tilgjengelige ressurser til å gjennomføre dem.

\section{Mette Sagsveen}

msagsveen@yahoo.com

Tidsskriftet

\section{Litteratur}

Fontaine O, Kosek M, Bhatnagar S et al. Setting research priorities to reduce global mortality from childhood diarrhoea by 2015. PLoS Med 2009; 6: e1000041. doi: 10.1371/journal.pmed.1000041.

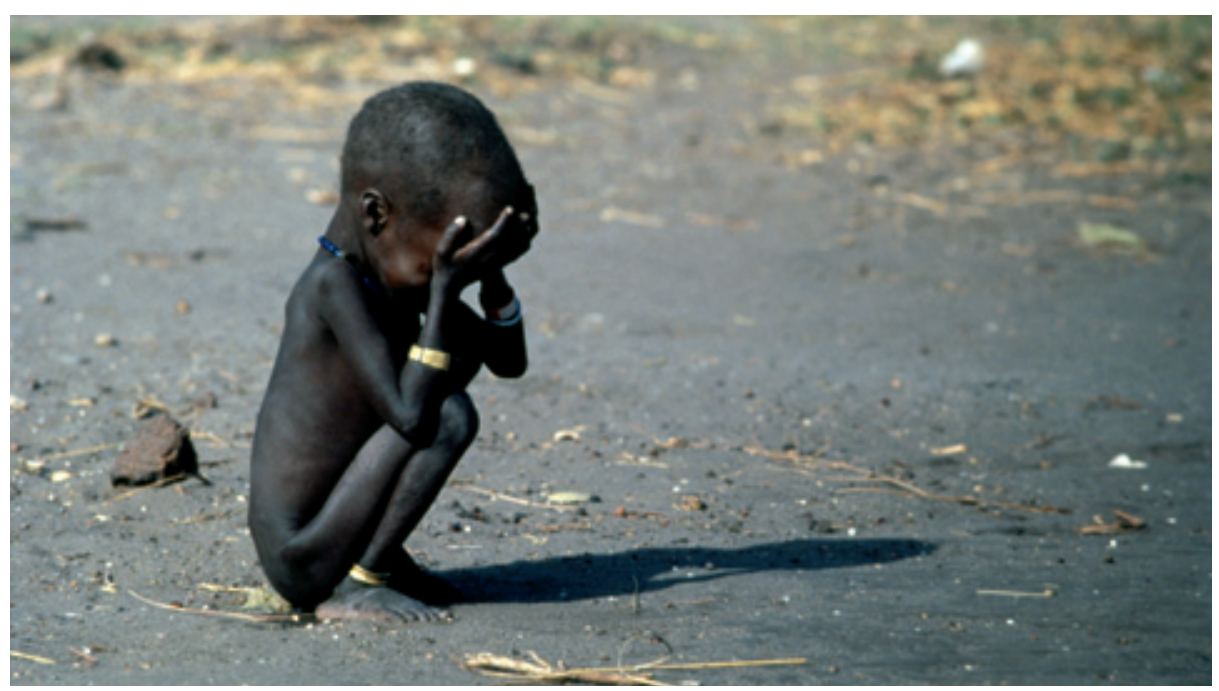

Underernæring er ofte underliggende årsak ved dødsfall forårsaket av diaré hos barn. Illustrasjonsfoto (c) Sygma/Corbis/SCANPIX 